に保菌䊿が見出された，保菌鷄では，羽毛，皮膚および 盲・直腸にサルモネラが分布し，とくに羽毛からの検出 率が高かった。保有菌量は羽毛は一般に低く，皮䖉。内 臟では高い場合が多かった。

2）処理場での工程が進むにつれ，污染菌量は少ない が, 污染率が增大する傾向が認められた。

3） 6 菌型が検出され，S. sofia の検出率がもっとも 高かった.

4）生鶏，と体拉よび脱毛機に分布するサルモネラの 菌型和よび薬斉耐性パターンは処理場により異なる傾向 が示された.

以上の成績から, 食鳥肉のサルモネラ污染は, 保菌䳕 によって招来されるものであり，污染拡大の要因とし て, 脱毛, 内臟摘出扣よび冷却工程が重要之思われた。
終わりに臨み，終始，ご指導ご鞭達を睗わった予研今 泉部長, 勝部博士ならびに圾崎博士に深謝いたします。

$$
\text { 文献 }
$$

1) 塚本定三：日獣会誌 $26,66 \sim 69$ (1973)。 2) G. K. Morris, et al. : Appl. Microbiol. 19, 795 799(1970). 3) 一阔陭秀婎：日獣会誌，24.18２2(1971)。4) 鈴木 昭：メディヤサークル，14, 308〜315 (1969). 5) 渡边 昭宣：日獣会誌，23，275 282 (1970). 6) 渡辺昭宣： 日獣会誌, 24, 186 191 (1971). 7) M. A. WeIssman, et al.: Appl. Microbiol. 17, 899 902(1969). 8) 橋本 秀夫：メディヤサークル，13, 251 260 (1968). 9) 坂 崎利一：食品衛生研究，12, 57〜58 (1962). 10) - 日本 公息衛生協会：微生物検査必携 (1966).

11) 余田 岬：第 75 回日本獣医学会抄録.

\title{
家亩 得线
}

\section{マレック病ワクチンの死亡とう汰拈よび抗体の産生に与える影響}

山田進二* 内布洋一* 幸田祐一* 時吉幸男* 藤川英雄 $*$

(昭和 47 年 7 月 27 日受付)

Causes of Death and Culling and Antibody Responses of Chickens to Several

Pathogens in the Presence of Herpes Virus of Turkey

Shinji Yamada, Y. Uchinuno, Y. Koda, S. TokiYoshr and H. FujiKawa

(Chemo-Sero-Therapeutic Research Institute,Inc., Kumamoto)

SUMMARY

Five trials were carried out with more than 15,000 chickens, including approximately 10,000 birds inoculated with Marek's disease vaccine (Deptavac-HV T). Each trial lasted for 180 days.

The disease broke out in $7.5 \%$ of the vaccinated birds and $14.4 \%$ of the unvaccinated control ones. The rate of decrease in outbreak of the disease in the vaccinated birds was $48.1 \%$. Death and culling occurred from a variety $f$ causes, including weakness accidental death, cannibalism, Marek's disease, leucosis, and chronic respiratory diseease.
There was no significant difference in positive rate for gel-precipitating antibody against Marek's disease, mean titer of neutralizing antibody against infectious bronchitis virus, or positive rate for agglutination against Mycoplasma gallisepticum between the vaccinated and control groups. When some vaccinated birds were subsequently inoculated with killed or live Newcastle disease vaccine 2 to 4 times during a period from 4 to 143 days of age no hemagglutinatio-ninhibiting antibody response to this vaccine was suppressed in any of 4 vaccinated groups.
マレック病はここ数年来ひなの肎成率低下の大きな原 因として問題になっていた。最近わが国でもマレック病 に対するワクチンが検討され，実用化された. マレック 病ワクチンはマレック病に効果があるばかりではなく， 他の疾病の発生に対して子影響を与え, 死亡とら汰数を 減少させると報告された ${ }^{1,3 \sim 6)}$ 。 なた，他種ワクチンの効 果に及ぼす影響についても検討がなされつつある2。.
著者らはマレック病ワクチンの野外陚験を行ない,き わめてよい結果を得たが，その成績についてはすでに報 告した ${ }^{9)}$. この野外試験実施時に死亡とう汰された鵎を 詳細に観察し，その原因を，また，いっぽらではとら汰 鶏血清を用い， $2 ， 3$ 病原体に対する抗体の変動もあわ せて検討してきた.これらの成績をマレック病ワクチン 接種有無の点からまとめたので報告する。

\footnotetext{
* 化学及血清療法研究所 (熊本市古京町 3-1)
} 
山田進二 内布洋一 幸田祐一 時吉幸男 藤川英雄

表 1 マレック病ワクチン接種有無による死亡とら汰数の比較

\begin{tabular}{|c|c|c|c|c|c|c|c|c|c|c|c|c|c|}
\hline \multirow{3}{*}{ 死亡とら汰原因 } & \multicolumn{8}{|c|}{ 地 } & \multicolumn{4}{|l|}{ 区 } & \multirow[b]{3}{*}{ 発生減少率1 } \\
\hline & \multicolumn{2}{|c|}{$\overbrace{}^{1}$} & \multicolumn{2}{|c|}{$\underbrace{2}$} & \multicolumn{2}{|c|}{$\underbrace{3}$} & \multicolumn{2}{|c|}{$\underbrace{4}$} & \multicolumn{2}{|c|}{$\underbrace{5}$} & \multicolumn{2}{|c|}{$\underbrace{\text { 訫 }}$} & \\
\hline & 接種 & 対照 & 接種 & 対照 & 接種 & 対照 & 接種 & 対照 & 接種 & 対照 & 揬種 & 対照 & \\
\hline 弱虚ひな & 61 & 45 & 21 & 15 & 19 & 16 & 62 & 8 & 48 & 8 & 211 & 92 & $12.1^{*}$ \\
\hline 事 故 & 24 & 0 & 13 & 2 & 13 & 1 & 44 & 12 & 27 & 7 & 121 & 22 & $168.8^{*}$ \\
\hline カソニバリズム & 22 & 9 & 15 & 10 & 8 & 3 & 15 & 4 & 8 & 10 & 68 & 36 & 7.7 \\
\hline 発䏍不良 & 0 & 10 & 10 & 11 & 0 & 1 & 3 & 6 & 25 & 4 & 38 & 32 & 58.0 \\
\hline マレック病 & 36 & 123 & 38 & 132 & 11 & 19 & 10 & 40 & 21 & 41 & 116 & 355 & 84.0 \\
\hline 由血病 & 5 & 10 & 4 & 8 & 0 & 1 & 1 & 0 & 0 & 0 & 10 & 19 & 74.3 \\
\hline C R D & 1 & 4 & 8 & 12 & 0 & 1 & 3 & 0 & 19 & 10 & 31 & 27 & 43.4 \\
\hline コリーザ & 0 & 1 & 1 & 3 & 0 & 0 & 1 & 1 & 2 & 1 & 4 & 6 & 67.4 \\
\hline 腹 膜 炎 & 1 & 2 & 2 & 0 & 0 & 2 & 1 & 1 & 1 & 0 & 5 & 5 & 51.1 \\
\hline 肝 炎 & 1 & 0 & 0 & 1 & 0 & 0 & 1 & 1 & 3 & 2 & 5 & 4 & 38.9 \\
\hline 腎炎 & 1 & 1 & 0 & 1 & 0 & 1 & 0 & 0 & 1 & 2 & 2 & 5 & 80.4 \\
\hline 䅌 炎 & 0 & 0 & 1 & 0 & 0 & 1 & 0 & 1 & 3 & 1 & 4 & 3 & 38.8 \\
\hline 卵策異常 & 0 & 0 & 1 & 1 & 0 & 1 & 3 & 0 & 1 & 0 & 5 & 2 & $22.2^{*}$ \\
\hline 痛風 & 0 & 2 & 0 & 1 & 0 & 0 & 0 & 1 & 1 & 0 & 1 & 4 & 87.5 \\
\hline 脳炎 & 0 & 0 & 0 & 2 & 0 & 1 & 0 & 0 & 0 & 1 & 0 & 4 & 100.0 \\
\hline 化膿性炎 & 0 & 0 & 0 & 0 & 1 & 0 & 0 & 0 & 1 & 1 & 2 & 1 & 2.3 \\
\hline 腫 演 & 0 & 0 & 0 & 1 & 0 & 0 & 1 & 0 & 0 & 1 & 1 & 2 & 75.6 \\
\hline 腸 炎 & 0 & 0 & 0 & 0 & 0 & 1 & 0 & 0 & 1 & 0 & 1 & 1 & 51.1 \\
\hline 関 節 炎 & 0 & 0 & 0 & 0 & 0 & 0 & 0 & 0 & 0 & 0 & 0 & 1 & 100.0 \\
\hline 不 明 & 26 & 24 & 25 & 19 & 18 & 22 & 26 & 15 & 39 & 14 & 134 & 94 & 30.3 \\
\hline 計 & 178 & 232 & 139 & 219 & 70 & 71 & 171 & 90 & 201 & 103 & 759 & 715 & 48.1 \\
\hline 発生減少率 ${ }^{1)}$ & & .4 & & .5 & & .7 & & 5.8 & & .8 & & 3.1 & \\
\hline 供 試 数 & 2000 & 1000 & 2000 & 1000 & 2100 & 2050 & 2074 & 1028 & 2000 & 894 & 0174 & 4972 & \\
\hline
\end{tabular}

注：1）対照群の発生数を 100 とした場合の接種群の発生減少率， *接種群の発生数が多かったもの, 数字は增数 した割合を示す。

\section{実験材料および方法}

ひな:デカルブ, バブコックおよびシェバースターク ロス288系の 1〜2 日齢ひなを用いた。

ワクチン：アメリカのメルクシャープアンドドームイ ンコーポレーテッド社製の生ワクチン(Deptavac-HVT) を使用した.このワクチンは七面鳥へルペスウイルス $(\mathrm{H}$ $\mathrm{VT}$ ）をアヒル胎児培養細胞で增殖させた材料から作成 されたものである.

ワクチン接種方法 : 涷結保存しているワクチンを流水 中で溶解し，これを添付の溶解液に加光希釈する，ワク チンは振とう混和後供試ひなの腹腔内叔よび皮下に 1 羽 分 (1,000 PFU) $0.2 \mathrm{ml}$ 宛接種した.

死亡とう汰原因の检討 : 臨床症状, 病理解剖拉よび組 織学的所見を綜合的に検討し死亡とう汰の原因を決定し た. 各藏器はホルマリン固定後切片標本を作成してへマ トキシリン・エオジン染色を行ない観察した。検查した 臟器は肝, 脾, 腎, 心, 肺, 神経, 脳, 腺胃扎よび腸で ある.いずれも死亡とう汰の原因となり得る病変をとり まとめたが, 数種類の病変を認めたものは最も強く出現 した変化を原因とした．観察は180日間行なった。
抗体の測定方法：マレック病についてはゲル内沈降抗 体を検討したが，寒天および抗原作成法ならびに術式は すでに述べた方法 ${ }^{8}$ によった。伝染性気管支炎（I B) は中和抗体を測定したが，鷄腎細胞および I Bウイルス 練馬株を用い，すでに述べた方法7゙により行なった。 = ュ一カッスル病（ND）赤血球凝集抑制（H I ）抗体は 家畜伝染病診断学の方法に準じて実施した. マイコプラ ズマ・ガリセプチカム凝集 $(\mathrm{MG})$ 反応は陚験管法で行 ない，血清希积 50 倍以上を陽性とした。

\section{実 驗 成 績}

\section{I 、死亡とう汰原因}

野外試験時死亡とう汰された鵎については臨床，解剖 扣よび病理組織学的に検索を行ない，原因の決定は綜合 的に行なった。 その結果表 1 に示すごとさ成績が得られ た。

死亡とら汰原因の主なものは虚弱ひな, 事故, カンニ バリズム，発育不良，マレック病，白血病打よび慢性呼 吸器病（CRD）であった. なおマレック病は日迹が 30 日歯以上で神経症状があり, 内臟, 眼, 皮膚, 笳肉など に病変があり,病変は結節型で, 腫大がそれほど著しくな 
図 1 マレック病ウイルスゲル内沈降抗体陽性率の動き

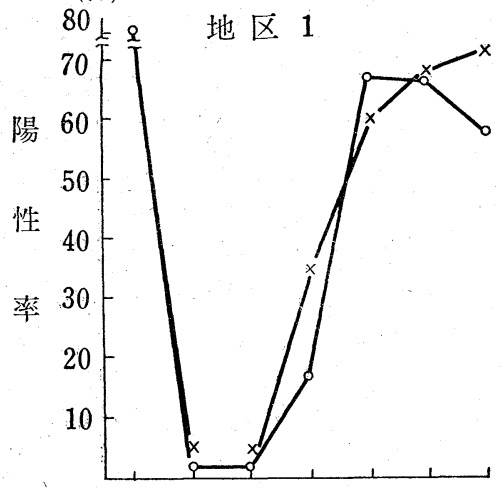

地区 2
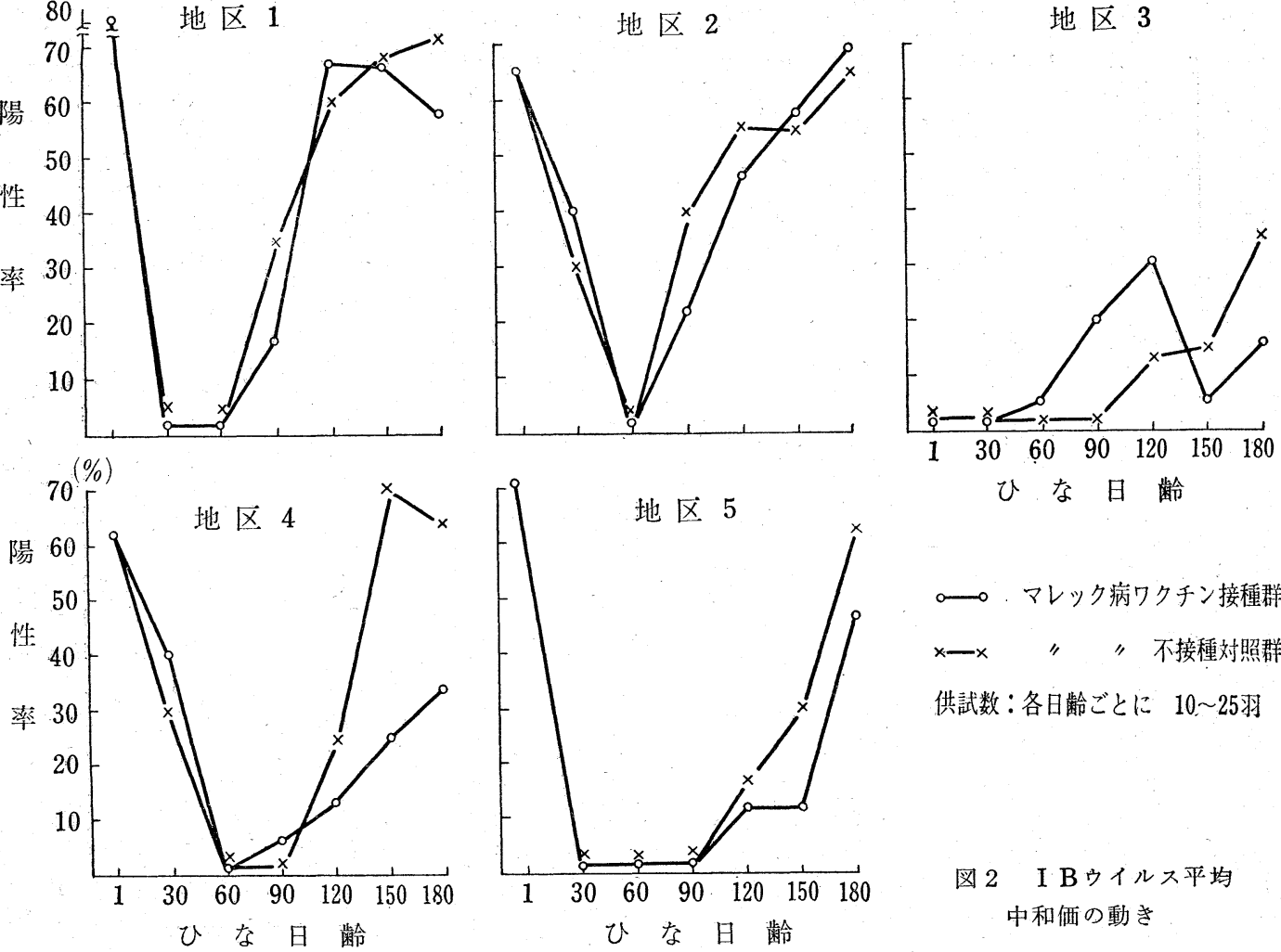

○一マレック病ワクチン接種群

×-х " " 不接種対照群

供試数：各日齢ごとに $10 〜 25$ 羽

図2 I B ウイルス平均 中和価の動き

地区 2 ,
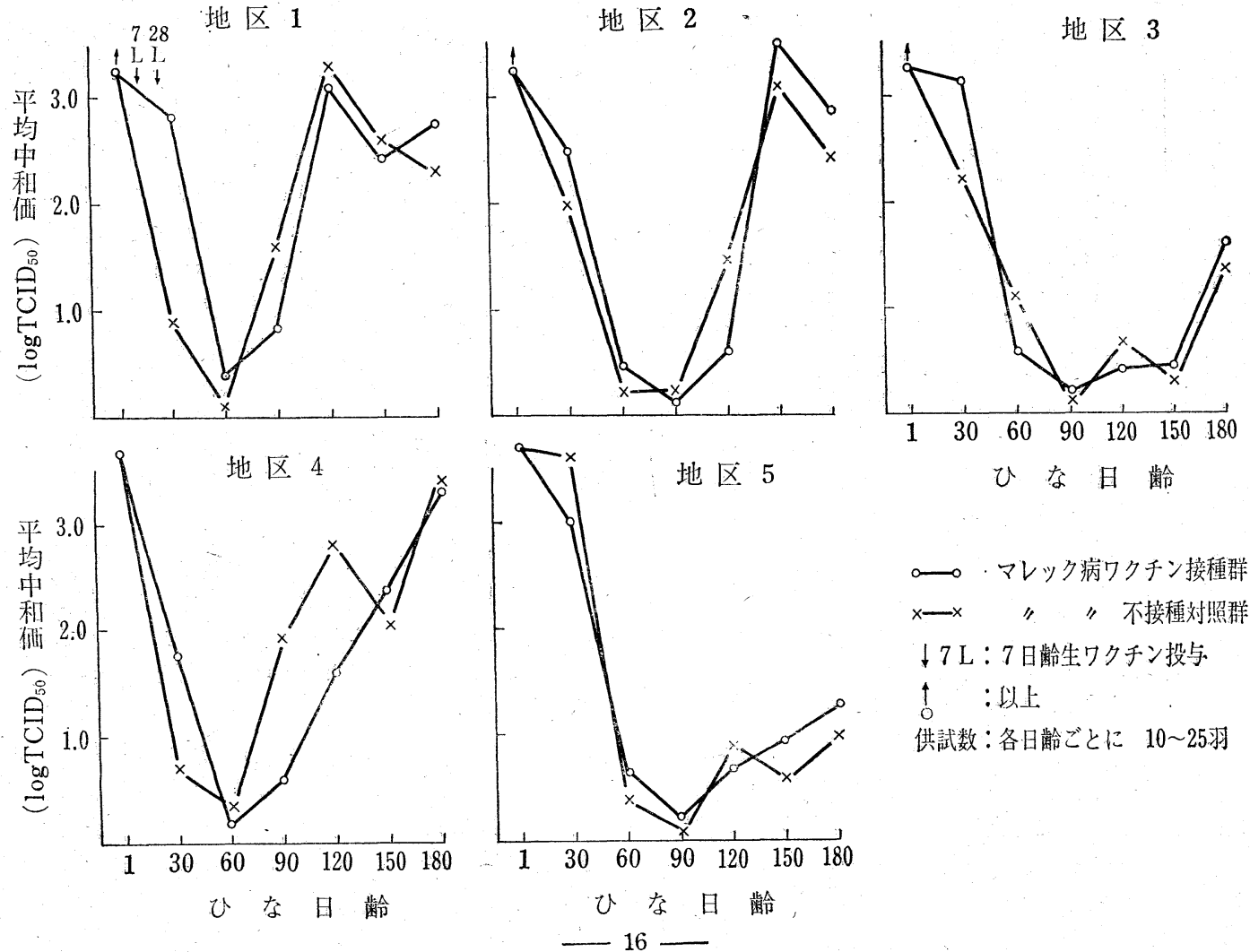

—・マレック病ワクチン接種群

×— " " 不接種刘照群

$\downarrow 7$ L : 7 日齢生ワクチン投与

$\uparrow_{0}$ :以上

供試数：各日齢ごとに 10 ～25羽 
図3 $M G$ 凝集抗体陽性率の動き
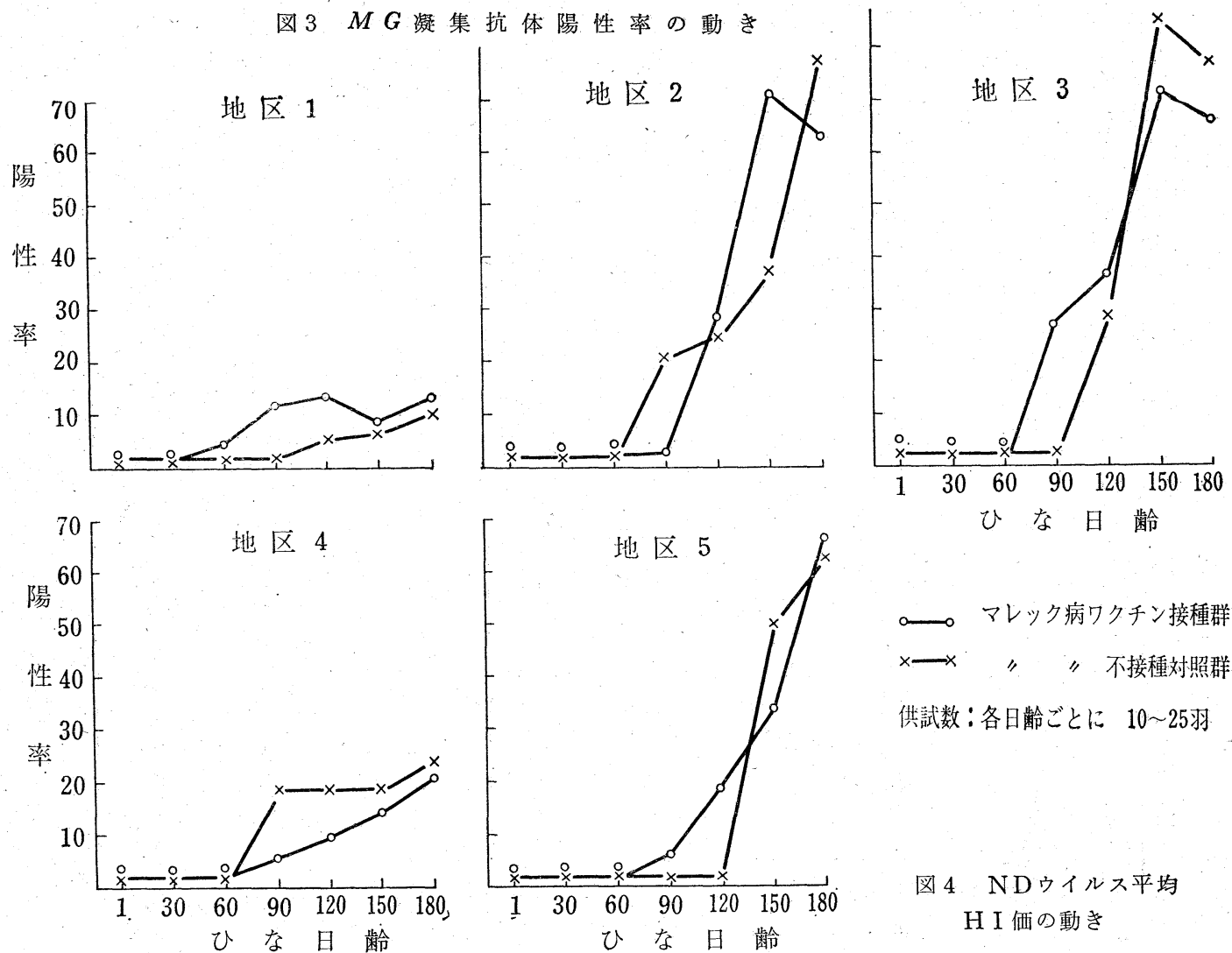

œ マレック病ワクチン接種群
$\times — \times \quad "$ 不接種対照群

供試数：各日齢ごとに $10 \sim 25$ 羽

図 4NDウイルス平均 H I 価の動き

地区 1
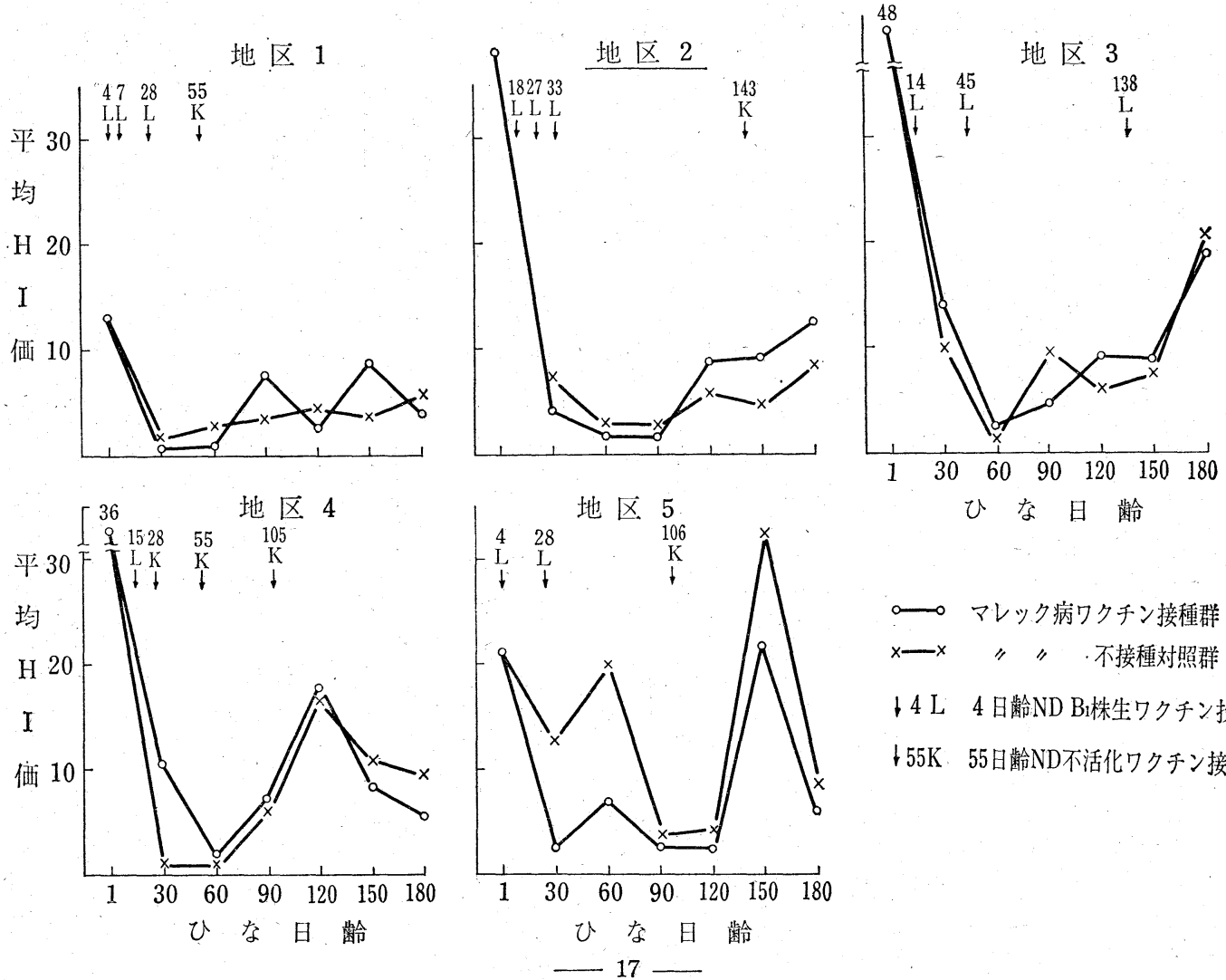

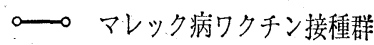
×—x " " ·不接種対照群

\4 L 4 日齢ND B1株生ワクチン投与 †55K５5日齢ND不活化ワクテン接種 
く, 病変部の細胞は大小不同のリンパ様細胞から構成さ れているものを綜合的に判定し, リンパ性白血病と区別 した. またマレック病とリンパ性白血病と明瞭に区別で きないものはマレック病としてまとめた.

地区別に多発した死亡とう汰原因をあげると虚弱ひな では地区 $1 ， 4$ および 5 , 事故では地区 4 および 5 ，力 ンニバリズムは地区 1 就よび 2 , 発育不良は地区 2 抽 よび5, マレック病拈よび白血病は地区 1 および 2 , な らびにCRDでは地区 2 および 5 であった. これら死亡 とら汰原因を日齡別にみると虚弱ひなでは接種直後から 60 日㱓まで, 発育不良では 120 日龄まで出現し, カン ニバリズム拉よび事故では 180 日龄まで平均した発生を 示した、また，マレック病では 30 日龋より発生し, 180 日齢まで, 次第に增数し，150～180日齢時に最も多かっ た. CRDは 90 日齢より，また白血病は 120 日龄より 出現し，日㱓の進むとともに增数した，死亡とう汰数を 各地区ごとにみると, いずれも接種群よりも対照群が多 く，対照群の発生数を 100 とした場合の接種群の減少率 は 5.8 8 $68.5 \%$ であった.これら 5 地区を総計すると接 種群では 10,174 羽中 759 羽 $(7.5 \%)$, 対照群では 4,972 羽中 715 羽. $(14.4 \%)$ が死亡とら汰され, 接種群の発生 減少率は $48.1 \%$ であった。 また，死亡とら汰原因の中 で接種群の発生率が対照群よりも高いものは虚弱ひな, 事故抢よび卵巣異常で, その外の原因では対照群で発生 率が高かった。

\section{II. ワクチン接種有無と $2 ， 3$ 病原体に対する抗体の 動き}

とう汰された鷄の血清についてマレック病ウイルスゲ ル内沈降抗体, I Bウイルス中和抗体, およびMG抗体 保有状況について検討した. 収集された血清はマレック 病ワクチン接種時 ( 1 日齢), $2 \sim 30,31 \sim 60,61 \sim 90$, 91〜120，121〜150 および 151〜180 日啮に得られた向 清の抗体価の平均值をそれぞれ $1,30,60 ， 90,120$,

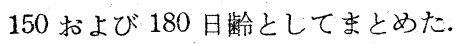

\section{i ） マレック病ウイルスゲル内沈降抗体の動き}

ワクチン接種および対照群のゲル内沈降抗体の陽性率 は図1に示すと打りである. 供試ひなの移行抗体陽性率 は地区 3 の $0 \%$ ものを除き62.5〜83.3\%を示した. そ の後30 60日齢時には移行抗体が消失し，陽性率は０\% となった。抗体陽性例の出現は地区によりかなり差を認 め，地区 $1 ， 2 ， 3$ および 4 では 60～90 日龄時より, 地区 5 では 120 日齢時より認め, 以後陽性率は上昇し た。また，180日踰時地区 3 の接種および対照群，地区 4の接種群のものでは15〜35\%の陽性率を示したが，そ の他の地区では 48～72\% の陽性率に達した．接種群と 対照群の陽性率の差をみると 10〜15\% の範囲内にある ものが多かったが，地区 4 では $30 \%$ の差を喼め，対照
群で高かった。 また，地区では接種扣よび対照群の抗体 の上昇時期に差が認められた。

\section{ii）I Bウイルス中和䄁体の動き}

ワクチン接種有無によるI Bウイルス中和抗体の平均 值は図 2 に示すとおりである，供試 5 地区のひなは全群 移行中和抗体を保有しており $1 \sim 2$ 日齢時 $3.2 \leqq$ 平均 中和価を示した．平均中和洒は 60〜90 日㢼時に最低と なり，以後次第に上昇した。地区 1 では 7 执よ゙ 28 日 齢時に I B生ウイルスワクチンを投与した.この地区で は30日嵝時の平均中和価は接種群では対照群に比較し高 かった。マレック病ワクチン接種有無で平均中和価に差 の認められた群は地区 4 のみで, 90〜120日齡時対照群が 接種群よりも平均中和洒で1. 2〜1.5高い值を示した. し かしその後 150 および 180 日龄時には差が現われなか った. その他の地区では接種および対照群の抗体の上杽 時期扣よび平均中和価の動きは同じ傾向を示した.

\section{iii） $M G$ 陽性率の動き}

$M G$ 抗体陽性率の動きは図 3 に示すとおりである. 1 日齢時移行抗体の検出でさた例はなかった. 地区 2,3 および5のものでは 90〜150日歯時から陽性率が急速に 高くなり, 最も陽性率の高い群では 85\% にも達した. 180 日齢時の抗体陽性率は地区 1 および，地区 4 のるの では他の 3 地区のものに比較し低い值を得た。また，各 地区の接種および対照群の陽性率間には差は誌められな かった。

\section{III. マレック病ワクチンの他種ワクチンの効果におよ ぼす影響}

野外試験に用いられた鷄群には一般に市貶されている ND生特よび不活化ワクチンを接種した. ここではマレ ック病ワクチン接種有無からみた抗体価の変動を検討し た. その成績は図4 に示すとおりである。

各地区ごとにNDワクチン接種プログラムが異なる ので地区別の比較はできなかったが，マレック病ワクチ ン接種有無で比較すると地区 $1,2,3$ 拈よび 4 では平均 H I 価に汪とんど差が認められなかった：地区 5 のもの では 30，60 扣よび 150 日齢時の平均H I 価に差があり 対照群に高い值が得られた。

\section{考察}

マレック病ワクチン野外試験の際に死亡とう汰の原因 となった主なものはコクシジウム，窒息，カンニバリズ ム, C R D, 内藏型痛風および蜔虫症であったと報告され ている ${ }^{5,6)}$. なた, マレック病に羅患した場合コクシジウ ム症に感受性が高くなることも述べられている5゙.. 今回 著者らが行なった野外試験の例では死亡とら汰された鶏 にコクシジウムの症例は認められなかった. 多発した死 亡とら汰の原因は，養鷄場により若干の差はあったが， 


\section{山田進二内布洋一 幸田祐一 時吉幸男 藤川英雄}

虚弱ひな, 事故,カンニパリズム, 発育不良, マレック病, 白血病，CRDなどであった，死亡とら汰原因の5ち虚 弱ひな，事故就よび卵巣異常を除き，その他の原因では 対照群で多かった.このように接種群で死亡とう汰数が 少なくなったことはワクチンウイルスが強毒マレック病 ウイルスによる発病を叔さえたため, 鵎に対するストレ スが減少したことによるためと思われる。

マレック病ワクチン接種群において, マレック病は対 照群よりも，発生が少なかったが，それでもかなりの数 を認めた。この点については,マレック病ワクチンは試験 養鷄場で接種されているので, 一部のひなで輸送中ある いは接種までの間に野外マレック病ウイルスに感染した ことが考学られる. また今回のマレック病発生数の集計 には白血病と明確に区別できなかったものも含まれてい ることも, マレック病発生数の多くなった原因であろら.

マレック病のダル内沈降抗体はいずれの供試鶏群にお いても，28〜33日㢼時にはウイルスが分離され ${ }^{9)}$, 野外マ レック病ウイルスが供試䊿群に浸入しているにもかかわ らず，60〜90 日歯封から上昇している地区扰よび 120 日齢時から上昇した地区と抗体上昇時期に差のあること を認めた.この原因として飼育環境, 飼育方法, 飼育密 度あるいは䳕の系統などが考えられるが，今回の試験で は，このいずれの点が原因であったのか確認できなかっ た. 陽性率が先の報告1,3、6) よりも若干低いが，これは 抗原作成方法および抗原の異なるためと考觉られる。

マレッュ病ワクチンの接種はND不活化ワクチンの免 疫効果に対し影響を与えないことが報告されている22. 今回の供試鷄群は 180 日齢時索でND生および不活化ワ クチンを $2 \sim 4$ 回投与されているが， 5 地区中 4 地区で はほとんどマレック病ワクチン接種有無に関係なく大略 同じ平均H I 価の動きを示した. 地区 5 では 30 および 60 日齡時，また，150日略時に若干平均H I 洒に差を認 めたが、マレック病ワクチン接種と関連性があったのか ぞうか判明しない:な怙今回の試験鵎群のらち1地区 （地区 1)でI B生ワクチンを投与した群があった。この 群の 30 日齢時の平均中和価に差を認めたが，これは供 試血清がマレック病ワクチン接種群のとら汰鷄が移行抗 体の消失しない幼龄時の方にかたよっていたためで、、 レック病ワクチンによる影響ではないと考えられる、し かしこの点は今後さらに検討して結論づけるべきことで あろら。

その他野外で広く分布しているマイコプラズマ，ガリ 七プチカム感染による抗体陽性率および I Bウイルス中 和抗体の産生にマレック病ワクチンが影響を与えていな いことがわかった。

\section{結論}

七面鳥ヘルペスウイルスを用いたマレック病生ワクチ
ン (Deptiavac-HVT) の野外試験時死亡とら泜した鷄 の原因, とう汰鶏血清を用いて 2,3 病原体の抗体の動 きを検討したところ，次のごとき成績が得られた。

1) ワクチン接種群の死亡とら汰率は $7.5 \%$ であた が, 対熙群では $14.4 \%$ で, 接種群は対照群に比較し死 亡とら汰率が $48.1 \%$ 減少した.

2) 死亡とら汰原因の主なものは虚弱ひな, 事故, 力 ソニバリズム, 発育不良, マレック病, 白血病, CRD などであった，虚弱ひな，事故および卵巣異常を除いた 死亡とう汰原因はワクチン接種群で詨照群よりもその発 生が少なかった。

3）マレック病ウイルスのゲル内沈降抗体の動きはワ クチン接種扎よび対照群の間に差を認めなかった。

4） B I ウイルス中和抗体価およびマイコプラズマ・ ガリセプチカム凝集抗体陽性率の上昇はワクチン接種お よび対照群の間に差を認めなかった。

5) ワクチン接種群のニューカッスル病生および不活 化ワクチン接種後の平均 H I 価の動きは 5 群中 4 群に差 を認めなかった. 他の1群では 30，60 および 150 日齢 時に対照群で平均H I 価が高かった。

\section{文献}

1) Biggs, P.M., L.N. Payne, B.S.Milne, A.E. ChurChill, R.C. Chubb, D.G. Powell and A. H. Harris: Vet. Rec. 87. 704 (1970). 2) Box, P.G., I.G.S. FumINGER and D. WARDÉN: Vet. Rec. 89, 475 (1971). 3) Eidson, C.S., D.P. Anderson, S. H. Kleven and J.BRown: Avian Dis. 15, 312 (1971). 4) GoAn, H.C.,C.C. Sheppard and H. G. Purchase: Poult. Sci. 51, 211 (1972). 5) Muelemans, G., P.Halem, P.Schyns and D. Bruynooghe: Vel. Rec. 89, 325 (1971). 6) PuRChase, H.G., W. Okazaki and B.R. Burmester: Poult. Sci. 50, 775 (1971)。 7) 山田進二, 落合美和子, 藤川 英雄, 内布洋一, 幸田祐一：日獣会誌, 24, 121 (1971). 8) 山田進二, 時吉幸男, 幸田祐一, 藤川英雄, 内布 洋一，立山幸男：家畜保健衛生技術研究会 報, 19, 26 (1971)。9）山田進二, 内布洋一, 幸田祐一, 時吉幸 男, 藤川英雄, 水野喬介, 小原速美, 市原、強, 秦 敦 朗, 阿部弘：日獣会誌, 投稿中.

\section{近刊予告}

\section{犬の内科学 \\ 予約 価 11,000円 送料 400 円}

